\title{
MORALITY ENFORGEMENT THROUGH THE CRIMINAL LAW AND THE MODERN DOCTRINE OF SUBSTANTIVE DUE PROCESS
}

\section{Thomas L. Hindes $\dagger$}

American society has available a wide array of tools to influence the conduct of its members, ranging from education and persuasion to deadly force. Yet it has been all too willing to employ that device at the latter end of this spectrum-the criminal sanction-to enforce moral values resting, at best, on the periphery of legitimate societal concern. The criminal codes of our state and federal governments contain numerous prohibitions of acts that do not seem to involve harmful consequences to others besides the actor. In some instances, conduct is prohibited even though morality appears to be the only value protected by the prohibition. Although forceful repression of deviant behavior has been common to all political systems, American society does not sanction the use of the criminal law to repress all conduct inconsistent with majoritarian moral values.

Elementary constitutional law dictates that we have a limited government. Certain areas of purely individual concern, guaranteed by the Constitution are protected from governmental intrusion without some "compelling" reason justifying the intrusion. ${ }^{1}$ This Article considers the extent to which government may use the criminal sanction to coerce competent adults consistently with individual liberty. It examines some of the common criminal proscriptions that have been found to be or arguably should be regarded as beyond the power of government to enforce, and notes the limitations upon governmental power currently recognized by the nation's judiciary and the traditional jurisprudential questions raised by the enforcement of morality. Finally, it advocates an approach to constitutional interpretation that will permit the government to carry out its legitimate function without unnecessarily abridging personal liberty.

† Associate Professor of Law, West Virginia University. J.D. 1968, University of Kentucky. This Article was partially completed with support from the West Virginia University Foundation. I would like to thank my colleagues James A. McLaughlin and Frederick F. Schauer for their many thoughtful comments and suggestions, and a succession of research assistants who have aided immeasurably in the preparation of this Article: Michael Parham, Terrence Gurley and Sam Byrer.

1 See, e.g., Roe v. Wade, 410 U.S. 113, 154 (1973). For a further discussion of this concept, see text accompanying notes 149-152 infra. 
I.

Consider, for example, the prohibition of marijuana use in American society. The criminal laws in every state proscribe the sale of the drug or its possession in large quantities, and in most states possession of any quantity, no matter how small, is a criminal violation. ${ }^{2}$ Such a proscription is surprising in light of the lack of reliable evidence of marijuana's harmful effects. In fact, over eighty years ago, the Indian Hemp Drugs Commission concluded that:

In all but the most exceptional cases, the injury from habitual moderate use [of hemp drugs] is not appreciable. The excessive use may certainly be accepted as very injurious, though it must be admitted that in many excessive consumers the injury is not clearly marked. The injury done by the excessive use is, however, confined almost exclusively to the consumer himself; the effect on society is rarely appreciable. It has been the most striking feature in this inquiry to find how little the effects of hemp drugs have obtruded themselves on observation. The large number of witnesses of all classes who professed never to

2 The general model for most state penal systems regulating marijuana and other "controlled substances" has become the UNIFORM Controlled Substances Act. As of the end of 1976, 43 states had adopted this Act, at least in part. 9 UNmorom LAws ANn. 39 (Supp. 1974-76). The essential reform accomplished by this Act, at least as pertains to marijuana, was a general reduction of penalties and a provision permitting judges to place first offenders on probation without adjudicating their guilt. UnIForm Controlred Substances ACT $\$ 407$. Under this provision, successful completion of the probationary period results in discharge of the proceedings.

At this time, eight states have passed statutes that either decriminalize the possession of small amounts of marijuana or make it a petty offense. In Alaska, for example, possession for private use of any amount of marijuana in a private place or one ounce in public by a person who is 18 years of age or older is a civil offense carrying a maximum fine of $\$ 100$. ATASKA STAT. $\$ 17.12 .110$ (1975). See Car. Healti \& SAFETx CoDE $\$ 11357$ (West Supp. 1976) (possession of one ounce or less is misdemeanor, carrying no permanent criminal record and a maximum fine of $\$ 100)$; Colo. Rev. Stat. $\$ 12-22-412$ (1973 \& Supp. 1976) (possession of one ounce or less is "class 2 petty offense," involving no permanent criminal record and maximum fine of \$100); MonN. STat. ANN. \$152.15 (West Supp. 1977) (possession or distribution without remuneration of one and one-half ounces or less is civil offense with maximum fine of $\$ 100$ for first offense); Ofro Rev. CODE AvN. $\$ 2925.11$ (Page Supp. 1977) (possession of less than 100 grams is a minor misdemeanor, imposing no criminal record and maximum fine of $\$ 100$ ); ORE. REv. STAT. $\$ 167.207$ (1975) (possession of less than one ounce is civil violation with maximum fine of $\$ 100$ ). See also 1977 S.D. Sess. Laws, ch. $189, \$ 92$ (possession of one ounce or less is class 2 misdemeanor, punishable by 30 days imprisonment or $\$ 100$ fine or both) (repealing 1976 S.D. Sess. Laws, ch. 158, $\$ \$ 42-46$ [possession of one ounce or less is petty offense equivalent to traffic ticket with fine set by state supreme court]). Compare ME. REv. STAT. tit. $22 \$ 2383$ (Supp. 1975) (possession of marijuana for personal use is civil violation with maximum fine of $\$ 200$ ) with $\mathrm{ME}$. REv. STAT. tit. 17-A, $\$ 1106$ (3) (1976) (possession of more than one and one-half ounces raises presumption of intent to distribute). 
have seen these effects, the vague statements made by many who professed to have observed them, the very few witnesses who could so recall a case as to give any definite account of it, and the manner in which a large proportion of these cases broke down on the first attempt to examine them, are facts which combine to show most clearly how little injury society has hitherto sustained from hemp drugs. ${ }^{3}$

These general conclusions as to the effects of marijuana use on the user and society have been repeatedly verified in numerous other inquiries. ${ }^{4}$ Indeed, even the most critical reports on the

3 Marijuana: Report of the Indian Hemp Drugs Commission 1893-1894, ch. 13, f 552 (J. Kaplan ed. 1969).

4 There have been several governmental studies of drug use, including marijuana or exclusively marijuana, between the Indian Hemp Drugs Commission Report in 1894 and the first report of the National Commission on Marijuana and Drug Abuse in 1972. A description of all these reports, except that of the National Commission, may be found in E. Brecher, Lictr and Irurarr Drugs 451-53 (1972). Because numerous books have been devoted in whole or in part to discussing marijuana, it would be presumptuous to suppose that the physical and emotional effects of marijuana use could be effectively summarized in this footnote. J. Kaptan, MaruJUANAThe New Pronisition 83-85 (1969), includes the following summary of the " "ordinary' effects of marijuana":

The most significant thing about the effects of marijuana is that the objective effects of the drug as measured in the laboratory are far less gross than the subjective effects. The objective physical effects are an increased heartbeat, a reddening of the conjunctiva, and, if it can be considered an objective effect, a dryness in the throat.

The objective mental effects of the drug, similarly, are far less gross than one might expect. Indeed, it is as yet impossible in the laboratory to devise any mental test that will consistently reveal anyone to be under the influence of marijuana. It does appear, however, that marijuana does adversely affect immediate memory and that while this has little effect on the performance of simple tasks, it does cause a noticeable decrease of the ability to perform complex tasks that require sustained levels of concentration and memory.

The most important and widespread ordinary effects of marijuana are a feeling of relaxation, a sense of euphoria, and an impression that one's senses have somehow been sharpened.

The mechanism of marijuana's effect is by no means clearly understood. One recent hypothesis-the first that seems to explain all the varied effects of the drug-is that marijuana's basic action is on the time sense. This causes a time distortion that to a greater extent than usual fixes the user upon the present moment rather than upon the past or the future. As a result he is temporarily freed from worries about the future or regrets about the past and hence is relaxed and mildly euphoric. Since he forgets boredom with past sensations, the user's present sensations seem newer and hence sharper and more intense. This applies to colors, taste, hearing, and the enjoyment of music and sex.

In addition, the fixation on the present tends to blur the usual categories by which we are accustomed to interpreting events and feelings. As a result the user will acquire-though to an extent far more limited than drug partisans. (especially of LSD) may suggest-new ways of looking at 
harmfulness of marijuana use leave marijuana in a category considerably more benign than such commonly used, and legally obtainable, items as cigarettes and alcohol. ${ }^{5}$

In view of the largely nonexistent scientific case against marijuana, the legal proscription against its sale and possession is questionable. Of course, the passage of a statute, such as one making marijuana possession criminal, does not require an objectively demonstrable case against the drug; a majority of legislative votes will suffice. Once a statute is passed and enforced by the police ${ }^{6}$ only the courts remain to pass judgment on its validity.

The constitutional challenges to marijuana statutes have primarily been of three types: (1) because marijuana is largely harmless, criminal sanctions against its use are arbitrary and, as such, violative of due process of law; (2) because other, more harmful drugs are freely available, prosecution of marijuana possessors is arbitrary and, as such, violative of equal protection guarantees; and (3) because marijuana is largely harmless, the imposition of criminal

events. Finally, the fixation on the present is not only a source of joy to the user. It can be extremely frightening-or, even if not so interpreted, can be quite unpleasant. This ordinary effect of marijuana is underrepresented in the sample of regular users. The reason is simply that those who tend to be frightened more often by the less rooted feeling of marijuana use are less likely to continue using the drug.

Historically the justifications for criminalizing marijuana have ranged from assertions that marijuana led to violent crime and to heroin addiction through more recent notions that marijuana caused brain damage, genetic defects, and sapped users of motivation to be productive members of society. All of these contentions have been considered and rejected in the studies referred to above. The National Commission on Marijuana and Drug Abuse found that marijuana was not a major threat to public health or a danger to public safety and did not lead to physical dependence or addiction to "hard" drugs. Specifically rejected were claims that the drug caused brain damage or genetic defects. Natronal Commussion on Marinuana and Drug Abuse, First Report: Marinuana: A Signal of Mtsunderstanding $84-85$ (1972) [hereinafter cited as FIRST REPORT]. In language reminiscent of that of the Indian Hemp Drugs Commission, text accompanying note 3 supra, the Commission noted that " $[t]$ he most notable statement that can be made about the vast majority of marihuana users-experimenters and intermittent users-is that they are essentially indistinguishable from their non-marihuana using peers by any fundamental criterion other than their marihuana use." Id. 41.

-There is no question that alcohol and tobacco are causing us far more health problems than marijuana does." The Washington Post, February $13,1976, \S \mathrm{A}$, at 7, col. 1 (quoting Dr. Robert L. Dupont, head of the National Institute on Drug Abuse). There is no evidence that anyone has ever died from an overdose of marijuana or from using the drug over a period of time, FIRST RePORT, supra note 4, at 56-57, a claim the cigarette and alcohol industries would be unable to substantiate for their products.

0 In 1974 alone there were 445,600 arrests. Federal BurEau of Investigation, UNIFORM CRIME REPORTS 179 (1974). Of course these figures do not reveal how many different individuals were arrested, how many of the arrests were merely for possession of marijuana, or how many arrests resulted in convictions. At minimum, however, the number of arrests alone reveals the tremendous burden the marijuana laws place on our criminal justice system. 
penalties for its possession amounts to cruel and unusual punishment.

All of these arguments are ultimately premised, at least in part, on the assumption that marijuana is virtually harmless, and courts have usually pointed to the presence of some contrary scientific evidence and the presumption of validity ${ }^{7}$ attaching to legislative acts as ample reasons to reject this assumption. ${ }^{s}$

Although several decisions have, because of a split court, amounted to something less than an unqualified endorsement of marijuana statutes, ${ }^{9}$ only one decision has invalidated such a statute solely on constitutional grounds. In Ravin $v$. State, ${ }^{10}$ the Alaska marijuana statute was found unconstitutional in part. Ravin was

7 See, e.g., United States v. Carolene Prods. Co., 304 U.S. 144 (1938) (party challenging state or federal statute has burden of rebutting presumptive constitutionality).

8 United States v. Drotar, 416 F.2d 914 (5th Cir. 1969), vacated and remanded on other grounds, 402 U.S. 939 (1971); Scott v. United States, 395 F.2d 619 (D.C. Cir. 1968), cert. denied, 393 U.S. 986 (1968); People v. Stark, 157 Colo. 59, 400 P.2d 923 (1965); United States v. Thorne, 325 A.2d 764 (D.C. 1974); Borras v. State, 229 So. 2d 244 (Fla. 1969), cert. denied, 400 U.S. 808 (1970); Raines v. State, 225 So. 2d 330 (Fla. 1969); State v. Kantner, 53 Haw. 327, 493 P.2d 306, cert. denied, 409 U.S. 948 (1972); Commonwealth v. Leis, 335 Mass. 189, 243 N.E.2d 898 (1969); Commonwealth v. Macek, 218 Pa. Super. 124, 279 A.2d 772 (1971).

9 In People v. Sinclair, 387 Mich. 91, 194 N.W.2d 878 (1972), six participating judges of the Michigan Supreme Court found four different reasons to reverse the conviction of John A. Sinclair. Sinclair, a campus political radical of some regional notoriety, had received a sentence of nine and one-half to ten years in prison for possession of marijuana; the evidence showed that he gave two marijuana cigarettes to undercover policemen. Three judges agreed that classifying marijuana as a "narcotic" was unreasonable and as such, it violated equal protection of the law. Accord, People v. McCabe, 49 Ill. 2d 338, 275 N.E.2d 407 (1971). Three judges thought that the sentence Sinclair received amounted to "cruel and unusual punishment," and two judges thought that the cigarettes were the fruits of an illegal entrapment and should have been excluded from evidence. Although he concurred in the last two reasons for reversal, Justice Kavanaugh also wrote that the marijuana statute amounted to "an impermissible intrusion on the fundamental rights to liberty and the pursuit of happiness, and is an unwarranted interference with the right to possess and use private property." 387 Mich. at 133, 194 N.W.2d at 896.

In State v. Kantner, 53 Haw. 327, 493 P.2d 306, cert. denied, 409 U.S. 948 (1972), two judges voted to affirm the defendant's conviction for possession of marijuana, rejecting an argument that classifying marijuana as a "narcotic" was unconstitutional. This argument was also rejected by a concurring judge who nevertheless went on to say that, were the issue properly before the court, he was not convinced that the state could meet its burden to "prove that the use of marijuana is not only harmful to the user but also to the general public before it can prohibit its use." Id. at 338, 493 P.2d at 313 (Abe, J., concurring). One dissenting judge believed that the regulation of marijuana possession violated fundamental personal rights of privacy and would have reversed the conviction for that reason. The other dissenter believed the classification of marijuana as a narcotic was unconstitutional. But cf. State v. Lee, 51 Haw. 516, 465 P.2d 573 (1970) (regulation of motorcycle helmets is within the police power as a matter of public interest although no clear link was shown between lack of a helmet and injury to others).

10537 P.2d 494 (Alaska 1975). 
arrested for possession of marijuana under circumstances that did not appear in the opinion, ${ }^{11}$ and he appealed from the denial of his motion to dismiss the indictment. He raised constitutional arguments based upon the denial of his right of privacy guaranteed by the fourteenth amendment and the Alaska Constitution ${ }^{12}$ as well as of equal protection. The Alaska Supreme Court discussed the two tier due process test applied in United States Supreme Court decisions and in other Alaska decisions: If the right infringed by governmental action is considered fundamental, the state must demonstrate a compelling reason for the infringement; if the right infringed is not fundamental, then only a reasonable relationship to some legitimate governmental purpose need be shown. ${ }^{13}$ Expressing dissatisfaction with this dual standard, the court decided that Ravin's privacy claim should be resolved

by determining whether there is a proper governmental interest in imposing restrictions on marijuana use and whether the means chosen bear a substantial relationship to the legislative purpose. If governmental restrictions interfere with the individual's right to privacy, we will require that the relationship between means and ends be not merely reasonable but close and substantial. ${ }^{14}$

Despite its apparent rejection of the fundamental right-compelling interest analysis, the court went on to decide that the right to smoke marijuana is not fundamental. ${ }^{15}$ Nevertheless, the court

11 According to an article on the decision published in Rolling Stone, Ravin was arrested for a muffler violation while driving his car. A search of the car revealed some marijuana and Ravin was arrested for possession. Treisman, Tokin' on the Tundra: Goldrush to Decriminalize Marajuana in Alaska, Rolring Srons, July 31,1975 , at 27.

12 "The right of the people to privacy is recognized and shall not be infringed. The legislature shall implement this section." ALAS. CONST. art. I, \$22.

13537 P.2d at $497-98$.

14 Id. 498.

15 Id. 502. This may perhaps be contrasted with a previous ruling of the Alaska Supreme Court to the effect that hair length choices were fundamental rights. Breese v. Smith, 501 P.2d 159 (Alaska 1972). Although Breese itself merely held that hair length was a fundamental right and that a school attempting to expel a student for violating a grooming regulation ("Male students' hair must not be down over the ears, over the eyes, ... [or] over the collar." Id. I6I) must show a compelling interest justifying the regulation, $i d$. 168-72, the decision was characterized in Ravin as one in which "the student's traditional liberty pertaining to autonomy in personal appearance was threatened in such a way that his constitutionally guaranteed right to an education was jeopardized." 537 P.2d at 502 . If the court is really suggesting that the ultimate effect of the infringement is a relevant factor in determining whether the particular right at issue is "fundamental," this would be a novel approach to classifying rights. Cf. San Antonio Independent School Dist. v. Rodriguez, 411 U.S. I, 30-3I (1973) (importance of service provided by state does 
read the privacy amendment to the Alaska Constitution ${ }^{16}$ and the United States Supreme Court decisions Griswold v. Connecticut ${ }^{17}$ and Stanley v. Georgia ${ }^{18}$ to create a fundamental right of "privacy in the home." This privacy right is subject to two limitations:

First, we agree with the Supreme Court of the United States, which has strictly limited the Stanley guarantee to possession for purely private, noncommercial use in the home. And secondly, we think this right must yield when it interferes in a serious manner with the health, safety, rights and privileges of others or with the public welfare. No one has an absolute right to do things in the privacy of his own home which will affect himself or others adversely. Indeed, one aspect of a private matter is that it is private, that is, that it does not adversely affect persons beyond the actor, and hence is none of their business. When a matter does affect the public, directly or indirectly, it loses its wholly private character, and can be made to yield when an appropriate public need is demonstrated. ${ }^{19}$

Although there may be no fundamental right to smoke marijuana, the court concluded that the "basic right" 20 to privacy in the home prohibits criminal sanctions for possession of marijuana "unless the state can meet its substantial burden and show that proscription . . . is supportable by achievement of a legitimate state interest." 21

The court then reviewed the evidence presented to the trial court concerning the medical and social aspects of marijuana use, concluding that, except for the effects of marijuana on driving ability, "there is no firm evidence that marijuana, as presently used in this country, is generally a danger to the user or to others." 22 Accordingly, the court held that no legitimate governmental interest in prohibiting marijuana use justified infringing the right of privacy in the home. The interest of the state in promoting traffic safety and the existing doubts as to the safety of the drug justified the

not determine fundamentality); id. 112-15 (Marshall, J., dissenting) (special significance attaches to education because of its effect on ability to exercise first amendment rights).

16 Note 12 supra.

17381 U.S. 479 (1965).

18394 U.S. 557 (1969).

19537 P.2d at 504. It becomes clear only later in the opinion that the court classifies actions harmful only to the actor as a matter of private concern. Id. 509 . 20 Id. 504.

$21 \mathrm{Id}$.

22 Id. 508. See J. Kaplan, Marujuana-The New Promibitron 276-86 (1970) (discussing marijuana intoxication and driving ability). 
general prohibition against marijuana cultivation, sale, or possession, but mere possession in the home may not be punished under the statute.

As a result of this decision, ${ }^{23}$ an adult may use and possess marijuana in his Alaska home, so long as the quantity possessed does not indicate an intent to sell. He may not, however, buy or sell the drug or use or possess it in a public place. In a subsequent case, the court affirmed the possession conviction of an individual who was involved in the sale of two pounds of marijuana. ${ }^{24}$ The court observed that Ravin was inapplicable when the possession was in a public place and incident to sale.

Even though the Ravin court was less than clear in delineating the precise constitutional standards by which it judged Alaska's marijuana laws, and its ultimate distinctions between possession in the home and in "public" and between possession and buying and selling are logically not quite consistent, ${ }^{25}$ the result is a laudable first step in the process of rationalizing our drug laws. Yet the prospect of other courts, particularly the United States Supreme Court, emulating the Ravin approach is remote. First, the Alaska court was construing the reach of an explicit recognition of individual privacy, recently added to the state constitution, to which courts in other jurisdictions may not have recourse. ${ }^{26}$ Second, the court relies on Stanley $v$. Georgia ${ }^{27}$ for a constitutional principle of privacy that goes well beyond the limiting language expressed in Stanley itself and the subsequent limitations on the principle delivered in Paris Adult Theatre I v. Slaton. ${ }^{28}$

Stanley has often been relied on by litigants urging the invalidity of marijuana and other drug laws and is almost as widely relied on by courts in rejecting such challenges. ${ }^{29}$ The appellant in Stanley was convicted of possessing obscene films, discovered in his bedroom drawer by police searching for evidence of bookmaking activities pursuant to a search warrant. Distinguishing Roth $v$. United States ${ }^{30}$ and other obscenity cases that involved some form

23 Shortly after this decision, Alaska substantially changed its marijuana laws. See note 2 supra.

24 Belgarde v. State, 543 P.2d 206 (Alaska 1975).

25 See text accompanying note 159 infra.

26537 P.2d at 500-03. See note 12 supra.

27394 U.S. 557 (1969).

28413 U.S. 49 (1973).

29 E.g., United States v. Drotar, 416 F.2d 914 (5th Cir. 1969), vacated and remanded on other grounds, 402 U.S. 939 (1971); Borras v. State, 229 So. 2d 244 (Fla. 1969), cert. denied, 400 U.S. 808 (1970).

30354 U.S. 476 (1957). 
of commercial exploitation of obscenity, the Court held that the government may not lawfully prosecute the mere possession of obscene materials in the privacy of one's own home. "If the First Amendment means anything, it means that a State has no business telling a man, sitting alone in his own house, what books he may read or what films he may watch." 31

Although the Court made some general references to a right of privacy, quoting part of Mr. Justice Brandeis' famous dissent in Olmstead $v$. United States, ${ }^{32}$ the opinion is unmistakably directed at protecting first amendment values. This caveat is most clearly set forth in the final footnote to the opinion, which Ravin did not address:

What we have said in no way infringes upon the power of the State or Federal Government to make possession of other items, such as narcotics, firearms, or stolen goods, a crime. Our holding in the present case turns upon the Georgia statute's infringement of fundamental liberties protected by the First and Fourteenth Amendments. No First Amendment rights are involved in most statutes making mere possession criminal. ${ }^{33}$

Any doubts concerning the breadth of Stanley's applicability were effectively resolved in Paris Adult Theatre $I$ v. Slaton. ${ }^{34}$ Paris Adult Theatre $I$ involved a civil action to enjoin the screening of two allegedly obscene films at Paris Adult Theatres I and II, establishments that gave notice at their joint entrance that "mature" films were shown within and apparently admitted only adults. Although the Georgia trial court denied the injunctive relief because of the Theatres' adults-only policy, the Georgia Supreme Court reversed the decision ${ }^{35}$ and, on appeal, the United States Supreme Court upheld the granting of injunctive relief.

31394 U.S. at 565.

32277 U.S. 438,478 (1928) (Brandeis, J., dissenting):

The makers of our Constitution undertook to secure conditions favorable to the pursuit of happiness. They recognized the significance of man's spiritual nature, of his feelings and of his intellect. They knew that only a part of the pain, pleasure and satisfaction of life are to be found in material things. They sought to protect Americans in their beliefs, their thoughts, their emotions and their sensations. They conferred as against the Government, the right to be let alone-the most comprehensive of rights and the right most valued by civilized man.

33394 U.S. at 568 n.11.

34413 U.S. 49 (1973).

35228 Ga. 343, 185 S.E.2d 768 (1971). 
Paris Adult Theatre $I$ is remarkable not so much for its limitation of Stanley to its facts, ${ }^{36}$ because other decisions had probably already accomplished that end, ${ }^{37}$ but rather for Chief Justice Burger's seeming endorsement of an exhaustive list of "legitimate state interests" involved in obscenity regulation. If obscenity is not protected speech under the first amendment and the privacy rights of Stanley are restricted to the home, the Chief Justice's extended canvas of societal values vindicated by obscenity regulation seems unnecessary. ${ }^{38}$ Necessary or not, the majority's discussion indicates just how far the present Court is likely to permit state and federal governments to regulate consensual adult activities that might be viewed as immoral by majoritarian values.

The Court rejected out of hand any suggestion that consenting adults may view obscene films in a theatre or other place open to the public as an exercise of the privacy right announced in Stanley, stating: "The idea of a 'privacy' right and a place of public accommodation are, in this context, mutually exclusive." 39 By its own admission, the majority was unable to distinguish between the state's interest in prohibiting a man and woman from performing an act of sexual intercourse "at high noon in Times Square" 40 from its interest in prohibiting the same conduct depicted on stage or screen before a group of adults who knowingly entered a theatre to see

36413 U.S. at 65-68.

37 See, e.g., United States v. Thirty-Seven (37) Photographs, 402 U.S. 363 (1971); United States v. Reidel, 402 U.S. 351 (1971). These cases involved commercial distributors of pornography who attempted to use the Stanley rationale by arguing that the material was purchased by adults for use in the home. This application of Stanley, which would go far toward overruling Roth v. United States, 354 U.S. 476 (1957), was rejected. The Reidel Court observed that "[t]he personal constitutional rights of those like Stanley to possess and read obscenity in their homes and their freedom of mind and thought do not depend on whether ... obscenity is constitutionally protected. Their rights to have and view that material in private are independently saved by the Constitution." 402 U.S. at 356 . As in Paris Adult Theatre I, the Court distinguished the commercial exploitation of pornography from the private use of pornography. Because Stanley was expressly premised on the first amendment, this distinction is not quite as apparent as the Court suggests.

38 Even though obscenity is not considered as protected speech under the first amendment, the state must still show that the proscription in the statute was rationally related to some legitimate legislative purpose. See Williamson v. Lee Optical, Inc., 348 U.S. 483 (1955). Given the rather automatic fashion in which this approach is used to sustain legislation, the Court could have disposed of the question without a great deal of discussion. For a contrary suggestion on this point, see Henkin, Morals and the Constitution: The Sin of Obscenity, 63 Corum. L. Rev. 391 (1963).

39413 U.S. at $66-67$.

40 Id. 67. 
such a depiction. ${ }^{41}$ What, one might ask, are the interests of government in prosecuting ${ }^{42}$ individuals who engage in either of these types of conduct? The Court's answer was to say that "these include the interest of the public in the quality of life and the total community environment, the tone of commerce in the great city centers, and, possibly, the public safety itself." 43 Although the opinion stops short of accepting as fact the "arguable correlation between obscene material and crime," 44 it finds a direct correlation between the proliferation of obscenity and our ability to maintain a "decent society." The concern expressed is for the "tone of society . . . the style of and quality of life, now and in the future." 45

The Court's lumping together of these two rather distinct classes of state interests-the prevention of crime said to be provoked by consumption of obscenity, and the cultivation of a decent society "[q]uite apart from sex crimes" ${ }^{46}$-is most disturbing. The legislature is not required to show with statistical certainty that its conclusions are correct, ${ }^{47}$ and perhaps it is empirically arguable, even if the minority view, that obscenity causes crime.48 But to say that the legislature in like manner may conclude that obscenity subverts the decency of society is to mask a judgment of a very different order behind a pretense of potential verifiability. To put a theater

41 The actual analogy used by the Court was the comparison between depicting or performing sexual acts on a theater stage and performing a sex act in public while discussing politics. Although political discussion during public sexual intercourse would clearly not furnish a constitutional defense in a prosecution for indecent exposure any more than reciting from the Bible while committing an axe murder would furnish a first amendment defense, the Court's utilization of this principle is inapposite to the context of obscenity regulation. The governmental interest in protecting the general public from obtrusive displays of lewd behavior should be considerably broader than the interest in regulating the movies or stage shows that are available to informed, consenting adults.

42 Although Paris Adult Theatre I was a civil case, neither the opinion itself nor other Supreme Court rulings on obscenity suggest that the holding would not be applicable to criminal prosecutions. As the Court noted, although the instant equity action "is civil in nature, and does not directly involve the state criminal statute proscribing exhibition of obscene material, the Georgia case law permitting civil injunction does adopt the definition of 'obscene materials' used by the criminal statute." 413 U.S. at 54 (footnotes omitted).

43413 U.S. at 58.

$44 \mathrm{Id}$. (footnote omitted).

45 Id. 59 (quoting Bickel, Dissenting and Concurring Opinions, 22 PUB. INTEREST 25, 25-26 (1971)).

46413 U.S. at 58-59.

47 Id. 61 (citing cases).

48 E.g., Report of the Commassion on Obscenity and Pornography 390-412 (1970) (minority report), cited 413 U.S. at 58 n.8. 
owner, and perhaps his patrons as well ${ }^{49}$, in prison because the films he has shown might harm the "tone" of society asserts an incredible arrogation of power over the lives of individuals.

The willingness of the present Supreme Court majority to embrace enthusiastically the governmental interests in regulating and proscribing obscenity suggests that it would summarily approve criminal statutes protecting the "decency" of society against activities that less clearly implicate the immunity of the first amendment. Such is not entirely the case, however. In now well-known cases the Court has found in the Bill of Rights, the fourteenth amendment, and, perhaps, the ninth amendment as well, limitations on governmental power to regulate the use and dispensing of contraceptives ${ }^{50}$ and the securing of an abortion. ${ }^{51}$

The first in this line of cases, Griswold $v$. Connecticut, ${ }^{52}$ is significant largely because it illustrates a variety of approaches to interpreting the general due process language of the fourteenth amendment. The illustrative value of the case is occasioned by the six different opinions required for the nine justices to express their approval or disapproval of Connecticut's anticontraception statute. Connecticut made the use of contraceptives a criminal offense, ${ }^{58}$ and aiding and abetting others to violate this statute was similarly proscribed. ${ }^{54}$ The Griswold defendants, appellants before the Supreme Court after the state court proceedings, were convicted of giving information, instruction, and medical advice about contraceptives to married persons.

Justice Douglas, joined by only Justice Clark, authored the opinion of the Court. In striking down the statute, Douglas invoked the incorporation doctrine..$^{55}$ Referring to the right of asso-

49 Although Stanley is the only case in which the Supreme Court has dealt with the prosecution of a consumer of pornographic material, the limitations imposed on the scope of that decision diminish its applicability to the arrest of an individual for watching a dirty movie in a "public" theater or for the public possession of obscene materials. Given the facility with which the Court can distinguish private use from commercial dissemination of obscene materials, they would presumably be capable of distinguishing private from public possession of such material. See F. ScFAUER, The LAw of OBSCENITy 175-76 (1976).

50 Eisenstadt v. Baird, 405 U.S. 438 (1972); Griswold v. Connecticut, 381 U.S. 479 (1965).

51 Doe v. Bolton, 410 U.S. 179 (1973); Roe v. Wade, 410 U.S. 113 (1973).

52381 U.S. 479 (1965).

53 Conn. Gen. Stat. Ann. $\$ \$ 53-32$ (1960) (repealed 1969).

54 Id. \$\$ 54-196 (repealed 1969).

55 The incorporation theory was given its broadest sweep in opinions authored by Justices Black and Douglas. Justice Black's dissent, joined by Justice Douglas, 
ciation guaranteed by the first amendment, the rights of security in one's home guaranteed by the third and fourth amendments, the personal privacy fostered by the privilege against self-incrimination, and numerous cases discussing these rights, Douglas found that "specific guarantees in the Bill of Rights have penumbras, formed by emanations from those guarantees that help give them life and substance." ${ }^{56}$ These rights and their penumbras create a right of privacy in the marital relation and are incorporated into the fourteenth amendment, thus protecting them against unnecessarily broad state regulation. Having cited a group of cases and constitutional provisions, most of which were facially unrelated to the issue at hand, Douglas concluded:

We deal with a right of privacy older than the Bill of Rights-older than our political parties, older than our school system. Marriage is a coming together for better or for worse, hopefully enduring, and intimate to the degree of being sacred. It is an association that promotes a way of life, not causes; a harmony in living, not political faiths; a bilateral loyalty not commercial or social projects. Yet it is an association for as noble a purpose as any involved in our prior decisions. ${ }^{57}$

in Adamson v. California, 332 U.S. 46 (1947), best illustrates the approach these Justices would take. Black argued:

the original purpose of the Fourteenth Amendment [was] to extend to all the people of the nation the complete protection of the Bill of Rights. To hold that this Court can determine what, if any, provisions of the Bill of Rights will be enforced, and if so to what degree, is to frustrate the great design of a written Constitution.

Id. 89. Also dissenting in that case, Justices Murphy and Rutledge agreed that the entire Bill of Rights was incorporated into the fourteenth amendment, but that the specific provisions of the first eight amendments should not operate to limit the scope of the fourteenth. Id. 124. Justice Black, ever the literal interpreter, was unable to take this additional step; witness his dissent in Griswold.

Perhaps the most forceful rebuttal of the mechanical approach that Justice Black advocated is found in Justice Frankfurter's concurring opinion in Adamson:

The short answer to the suggestion that the provision of the Fourteenth Amendment, which ordains "nor shall any State deprive any person of life, liberty, or property, without due process of law," was a way of saying that every State must thereafter initiate prosecutions through indictment by a grand jury, must have a trial by a jury of twelve in criminal cases, and must have trial by such a jury in common law suits where the amount in controversy exceeds twenty dollars, is that it is a strange way of saying it. It would be extraordinarily strange for a Constitution to convey such specific commands in such a roundabout and inexplicit way.

Id. 63. See Henkin, "Selective Incorporation" in the Fourteenth Amendment, 73 YALE L.J. 74 (1963); Kadish, Methodology and Criteria in Due Process Adjudication - A Survey and Criticism, 66 YaLE L.J. 319 (1957).

56381 U.S. at 484.

57 Id. 486. 
The Douglas opinion illustrates what many regard as a shortcoming of the incorporation approach to the fourteenth amendment. Even Justice Black, another adherent of this approach, commented in his dissenting opinion: "I like my privacy as well as the next one, but I am nevertheless compelled to admit that government has a right to invade it unless prohibited by some specific constitutional provision." 58 Although Justice Stewart regarded the Connecticut law as "uncommonly silly," 59 he, like Black, was unable to find any specific constitutional language to justify the majority's ruling. Placed against these dissenting views, Douglas' creativity in finding penumbras emanating from largely unrelated specific guarantees, unfolds as an attempt to adhere to incorporation where there was little to incorporate.

The concurring opinion of Justice Goldberg attracted the most support, gaining the support of Justices Warren and Brennan. Goldberg began by discounting the validity of the incorporation theory, asserting that "the concept of liberty protects those personal rights that are fundamental, and is not confined to the specific terms of the Bill of Rights." " 0 He then proceeded to outline a right, styled the "right of marital privacy," drawing considerable inferential support from the ninth amendment. ${ }^{61}$

The opinion delved to some extent into the history of the ninth amendment in order to assert that it was intended to guarantee against a limited interpretation of individual liberty: "It was proffered to quiet expressed fears that a bill of specifically enumerated rights could not be sufficiently broad to cover all essential rights and that the specific mention of certain rights would be interpreted as a denial that others were protected." ${ }^{82}$

Although Justice Goldberg stopped short of declaring that the ninth amendment, unlike the first eight, applied directly to the states or that it was "incorporated" into the fourteenth, he concluded: "In sum, the Ninth Amendment simply lends strong support to the view that the 'liberty' protected by the Fifth and Fourteenth Amendments from infringement by the Federal Government or the States is not restricted to rights specifically mentioned in the first

58 Id. 510.

59 Id. 527.

60 Id. 486.

61 "The enumeration in the Constitution, of certain rights, shall not be construed to deny or disparage others retained by the people." U.S. Const. amend. IX. See B. Patterson, The Forgotten Ninth Amendment (1955).

62381 U.S. at $488-89$. 
eight amendments." ${ }^{63} \mathrm{He}$ then asserted that an essential part of this liberty was the right of privacy in the marital relation and the marital home.

Even though Justice Goldberg did not purport to find this right explicitly in the Bill of Rights, the liberty he extracted is fairly specific. It is a right of marital privacy that will not permit forced interference with the home and family either to limit birth control or to promote it, at least in the absence of some "compelling" reason not present in Connecticut's anticontraception statute. ${ }^{64}$ The liberty recognized however, appears to extend only to the lawfully married. State regulation of promiscuous or deviant sexual conduct is not invalidated by Goldberg's notion of individual liberty. ${ }^{65}$

The opinions of Justices Harlan ${ }^{66}$ and White, ${ }^{67}$ concurring in the result, also disagree with Douglas' theory of incorporation. They both utilize a natural law interpretation of the fourteenth amendment, concluding that Connecticut's statute violated "basic values "implicit in the concept of ordered liberty." " 88 Justice

63 Id. 493.

64 Under the fundamental right-compelling interest approach, see text accompanying notes 149-52 infra, the government must demonstrate extremely important reasons to pass a statute that tends to inhibit the exercise of a fundamental right such as the right of marital privacy. As might be supposed, Connecticut was wholly unable to supply any such compelling reason (or any rational basis for that matter) to support the anticontraception statute. Perhaps realizing that to argue that the statute reflected religious views about the morality of contraception would be tantamount to confessing error, the state suggested that the statute promoted its interest in preventing premarital and extramarital sexual relationships. Even if the state has a legitimate interest in the prevention of illicit sex, banning contraceptive use by all individuals, married and single, is a rather absurd way of promoting such interests. The concurring opinions of Justice Goldberg, 381 U.S. at 486, 497-99, and Justice White, id. 502, 505-07, discuss this purported rationale and reject it.

65 Because Justice Goldberg bases his ultimate conclusion about the validity of the Connecticut statute on the "right of marital privacy," he finds no difficulty in the state's regulation of illicit sex, quoting with approval from Justice Harlan's dissent in Poe v. Ullman, 367 U.S. 497, 553 (1961):

Adultery, homosexuality and the like are sexual intimacies which the State forbids ... but the intimacy of husband and wife is necessarily an essential and accepted feature of the institution of marriage, an institution which the State not only must allow, but which always and in every age it has fostered and protected. It is one thing when the State exerts its power either to forbid extra-marital sexuality ... or to say who may marry, but it is quite another when, having acknowledged a marriage and the intimacies inherent in it, it undertakes to regulate by means of the criminal law the details of that intimacy.

381 U.S. at 499.

66381 U.S. at 499 .

67 Id. 502.

68 Id. 500 (Harlan, J., concurring). The "ordered liberty" approach is the general natural law standard for interpreting the fourteenth amendment taken from Justice Cardozo's opinion in Palko v. Connecticut, 302 U.S. 319, 325 (1937). 
White found "the broad ban [to be] of marginal utility to the declared objective" and violative of due process. ${ }^{62}$

The privacy right recognized in Griswold is today generally thought to encompass only the marital relationship and to be restricted to those aspects of the marital relationship that involve the marital home or some other "private" place. ${ }^{70}$ The reliance of Eisenstadt v. Baird ${ }^{71}$ on the equal protection clause in striking down a Connecticut statute that banned dispensing contraceptives or advocating their use to single people confirms the narrow scope of the due process right articulated in Griswold. ${ }^{2}$

The next judicial consideration of "governmental intrusion into . . . the decision whether to bear or beget a child," 73 concerned the validity of abortion laws. In the cases of Roe $v$. Wade ${ }^{74}$ and Doe v. Bolton, ${ }^{75}$ the Court held that individual liberty under the fourteenth amendment included a "right of privacy . . . broad enough to encompass a woman's decision whether or not to

69381 U.S. at 507.

70 See Paris Adult Theatre I v. Slaton, 413 U.S. 49, 65 (1973).

71405 U.S. 438 (1972).

72 The purported justifications for the statute at issue in Eisenstadt were: (a) to protect health by regulating the distribution of dangerous drugs; (b) to protect morals by regulating the sexual lives of single people; and/or (c) to promote marital fidelity. The Court observed that protecting morals could not reasonably be regarded as a legislative purpose, stating:

It would be plainly unreasonable to assume that Massachusetts has prescribed pregnancy and the birth of an unwanted child as punishment for fornication, which is a misdemeanor under Massachusetts General Laws Ann., c. $272, \$ 18$. Aside from the scheme of values that assumption would attribute to the State, it is abundantly clear that the effect of the ban on distribution of contraceptives to unmarried persons has at best a marginal relation to the proffered objective.

405 U.S. at 448 . The Court pointed out that contraceptives designed to prevent disease were widely available, legally and without prescription. Since the married person who is entitled to obtain contraceptives on prescription need not be living with his or her spouse and need not use the contraceptive exclusively during sexual relations with the spouse, reason (c) above clearly fails to furnish a rational basis for the statute.

If the reason for the statute was the protection of health, then the distinction between married and unmarried persons is unjustified. Quoting the court of appeals, the Court noted:

"If the prohibition [on distribution to unmarried persons] ... is to be taken to mean that the same physician who can prescribe for married patients does not have sufficient skill to protect the health of patients who lack a marriage certificate, or who may be currently divorced, it is illogical to the point of irrationality."

405 U.S. at 451, quoting Baird v. Eisenstadt, 429 F.2d 1398, 1401 (1st Cir. 1970) (bracketed material by Supreme Court).

73405 U.S. at 453.

74410 U.S. 113 (1973).

T5 410 U.S. 179 (1973). 
terminate her pregnancy." 76 After balancing the governmental interests in protecting the health of the mother and the rights of the embryo-fetus to life against this right of privacy, in order to discover the point at which the interest became "compelling," the Court concluded that: prior to the end of the first trimester, the abortion decision rests with the pregnant woman and her doctor; during the second trimester, regulations reasonably related to maternal health may be imposed; during the third trimester (or after the fetus is viable) the state may regulate to protect that fetal life by prohibiting abortions except in cases where the regulation would endanger the mother's life or health. ${ }^{77}$

Although criticism of Roe has been widespread, ${ }^{78}$ it is firmly rooted in our constitutional law even if not, as some critics contend, in the Constitution itself. As Justice Stewart's concurring opinion forthrightly observes, the decision is a product of the doctrine of substantive due process." Although the phrase "substantive due process" has generally been avoided by the Court and the doctrine itself has been thought to be moribund since the New Deal, ${ }^{80}$ it has never completely disappeared. The individual rights recognized in Meyer $v$. Nebraska ${ }^{81}$ and Pierce $v$. Society of Sisters ${ }^{82}$ retain their vitality to this day. Moreover, contemporary decisions such as Roe,

76 Roe v. Wade, 410 U.S. 113, 153 (1973).

77 Id. 164-65. Any question whether this right was personal to the woman was answered in Planned Parenthood v. Danforth, 428 U.S. 52 (1976), in which the Court declared invalid Missouri's requirement that the husband consent to abortions performed on his wife. The Court also struck down a statutory requirement of parental consent if the woman is an unmarried minor. It should be observed, however, that with respect to unwed minors a parental consent requirement that fell short of granting the parents an absolute veto might pass muster. Id. 89, 90-91 (Stewart, J., concurring).

${ }^{78}$ See, e.g., Ely, The Wages of Crying Wolf: A Comment on Roe v. Wade, 82 Yace L.J. 920 (1973); Epstein, Substantive Due Process By Any Other Name: The Abortion Cases, 1973 Sur. Cr. Rev. 159; O'Meara, Abortion: The Court Decides a Non-Case, 1974 Sur. Cr. Rev. 337.

79 Roe v. Wade, 410 U.S. 113, 167-68 (1973) (Stewart, -J., concurring).

80 See generally McCloskey, Economic Due Process and the Supreme Court: An Exhumation and Reburial, 1962 Sur. Cr. Rev. 34.

81262 U.S. 390 (1923). In this case, a Nebraska statute prohibiting the teaching of any foreign language to school children who had not yet completed eighth grade was found to violate due process. Because the Court did not believe that knowledge of a foreign language could reasonably be regarded as harmful, the statute was said to violate the teacher's right to teach and parents' right to have their children instructed.

82268 U.S. 510 (1925). An Oregon statute probibiting parents from sending children between the ages of eight and sixteen to private schools was struck down as an unreasonable interference with the rights of parents to direct the upbringing of their children. 
Griswold, and Loving v. Virginia ${ }^{83}$ clearly involve the doctrine. But the doctrine has been spottily applied without consistent anchoring to jurisprudential principles.

In spite of the rather bold stroke for individual liberty represented by the result in Roe $v$. Wade, the latter day version of substantive due process remains a rather timid ghost of its former self. Although the doctrine was formerly used to strike down social welfare legislation and economic regulation, ${ }^{84}$ it is now employed in considerably less sweeping fashion to protect noneconomic and more specific personal rights against governmental regulation.

Indeed, the liberty interest asserted by modern substantive due process is most obviously characterized by its specificity-that is, its narrowness. Individual liberty or "personal privacy," as it is currently termed, includes the right to marry the person of one's choice (presumably as long as that person is of the opposite sex, unmarried, and not one's brother or sister ${ }^{85}$ ), and once married a couple must be left free to make reasonable choices about the education and upbringing of any children of the marriage and to utilize contraceptive devices. Whether married or single an individual may not be restricted by governmental action from reasonable access to contraceptives, or prosecuted for possessing, in the privacy of the home, material that is concededly obscene by the Court's own evershifting standards. A woman has the right to make a decision about the continuation of a normal pregnancy under the aegis of her attending physician but largely free from state interference until the fetus is viable.

The spotty protection afforded by the privacy decisions does not simply reflect a dearth of decided cases in the domain of in-

83388 U.S. 1 (1967). This case declared Virginia's anti-miscegenation statutes unconstitutional as violative of both equal protection and due process under the fourteenth amendment. In its short discussion of due process, the Court observed that "[t]he freedom to marry has long been recognized as one of the vital personal rights essential to the orderly pursuit of happiness by free men." Id. 12.

84 E.g., Lochner v. New York, 198 U.S. 45 (1905). Although the high water mark of judicial interference with legislative attempts to regulate the economy was not reached until the 1930's, see McCloskey, supra note 80 , Lochner is symbolic of all the worst attributes of substantive due process. See generally Stephenson, The Supreme Court and Constitutional Change: Lochner v. New York Revisited, 21 VIIL. L. REV. 217 (1976).

\$5 Loving v. Virginia, 388 U.S. I (1967), recognized the right to marry the person of one's choice, but nothing in that case would justify applying this principle to homosexual, incestuous or bigamous marriages. See Reynolds v. United States, 98 U.S. 145 (1878) (prosecution for bigamy does not violate first amendment); Baker v. Nelson, 291 Minn. 310, 191 N.W.2d 185 (1971), appeal dismissed, 409 U.S. 810 (1972) (Griswold and Loving distinguished in suit by homosexuals seeking the right to marry each other); Drinan, The Loving Decision and the Freedom to Marry, 29 Orro ST. L.J. 358 (1968). 
dividual liberty; rather, it betrays an affirmative pattern of narrow decision and constriction by the Court. Stanley, of course, has been limited to its facts by Paris Adult Theatre $1 .^{86}$ Roe can hardly be read broadly enough to find application beyond the abortion issue, as the Court commented that "it is not clear to us that the claim asserted by some amici that one has an unlimited right to do with one's body as one pleases bears a close relationship to the right of privacy previously articulated in the Court's decisions." 87 The Roe Court in fact refrained from generalizing about the individual liberty that protects the woman's role in the abortion decision.

Griswold and Eisenstadt seem susceptible of only slightly broader application. One area in which the privacy rights articulated in those cases might be applicable is in criminal proscriptions against sodomy, fornication, and adultery. The majority's railing against pornography in Paris Adult Theatre $I$, however, indicates that the present Court would agree with the assertion in Justice Goldberg's concurring opinion in Griswold that the Griswold decision "in no way interferes with a State's proper regulation of sexual promiscuity or misconduct." 88 The most apposite Supreme Court decision on this point came in Doe v. Commonwealth's Attorney ${ }^{80}$ in which the Court affirmed, without opinion, the decision of a three-judge district court that refused to invalidate the Virginia sodomy statute. ${ }^{90}$ Although perhaps more specific than its counterparts in many other states, ${ }^{91}$ the Virginia statute is certainly not

86 See Richards, Free Speech and Obscenity Law: Toward a Moral Theory of the First Amendment, 123 U. PA. L. REv. 45, 71 (1974).

87 Roe v. Wade, 410 U.S. 113, 154 (1973). For a discussion of the jurisprudential debate over governmental paternalism, see text accompanying notes 121-25 infra.

88381 U.S. at 498-99 (Goldberg, J., concurring).

89 Doe v. Commonwealth's Attorney, 403 F. Supp. 1199 (E.D. Va. 1975), aff'd, 425 U.S. 902 (1976).

90 When suit was brought, the statute, since repealed, read:

Crimes against nature.-If any person shall carnally know in any manner any brute animal, or carnally know any male or female person by the anus or by or with the mouth, or voluntarily submit to such carnal knowledge, he or she shall be guilty of a felony and shall be confined in the penitentiary not less than one year or more than three years.

VA. CoDE $\$ 18.1-212$ (1960) (repealed 1975).

91 See, e.g., Mass. Gen. Laws ANN., ch. $272 \$ \$ 34-35$ (1972):

$\S 34$ Sodomy and Buggery.

Whoever commits the abominable and detestable crime against nature, either with mankind or with a beast, shall be punished by imprisonment in the state prison for not more than twenty years.

$\$ 35$ Unnatural and Lascivious Acts.

Whoever commits any unnatural and lascivious act with another person shall be punished by a fine of not less than one hundred nor more than one 
atypical. The challenge in Doe v. Commonwealth's Attorney was instituted by adult, male homosexuals who sought declaratory and injunctive relief, asserting that the statute was unconstitutional on its face and as applied to them because they allegedly faced the threat of prosecution.

In a two to one decision, the district court rejected the plaintiffs' contentions. Griswold was thought inapplicable because homosexual activity "is obviously no portion of marriage, home or family life . . . " 92 The majority felt that Virginia fulfilled its obligation to show a "rationally supportable" interest because "[f]undamentally, the State action is simply directed to the suppression of crime, whether committed in public or private." ${ }^{93}$ Although the majority apparently regarded this circular response as more than adequate, it proceeded to observe that homosexual "conduct is likely to end in a contribution to moral delinquency." 94 Doe presents quite a paradigmatic case of prosecution for activity that perceptibly affects at most the intangible "decency" of society, because the prohibition could not be said to stem from public health considerations, from a fear that homosexual activity breeds violent crime, or as a promotion of population growth. Only if society may punish conduct that is immoral by majoritarian values does a legitimate government interest underlying the Virginia sodomy law exist. ${ }^{95}$

thousand dollars or by imprisonment in the state prison for not more than five years in jail or in the house of correction for not more than two and one half years.

In Commonwealth v. Balthazar, 366 Mass. 298, 318 N.E.2d 478 (1974), the defendant was convicted of violating $\$ 35$ for allegedly forcing a woman to perform an act of fellatio on him and compelling her "to put . . . [her] tongue on his backside." Id. at 299, 318 N.E.2d at 479 (bracketed material by Massachusetts Supreme Court). The court held that the statute was not unconstitutionally vague as applied to Balthazar, but went on to observe that " $\$ 35$ must be construed to be inapplicable to private, consensual conduct of adults .... [because] the concept of general community disapproval of specific sexual conduct, which is inherent in $\$ 35$, requires such an interpretation." Id. at 302, 318 N.E.2d at 481 . The court refused, howvever, to base this dictum on constitutional grounds.

92403 F. Supp. at 1202.

$93 \mathrm{Id}$.

$94 I d$.

95 As I look at the matter, we are investigating in this part of our inquiry a course of conduct which is contrary to the best interests of the community, and one which can have very serious effects on the whole moral fabric of social life. It is one of those forms of conduct falling within the group to which the words of the Street Offences Committee ... apply as being "conduct it has always been thought right to bring within the scope of the criminal law on account of the injury which they occasion to the public in general.' The influence of example in forming the views and developing the characters of young people can scarcely be overestimated.... If the recommendation be adopted, the moral force of the law will be weakened. I am convinced that the main body of the community recognizes clearly the 
Although Doe v. Commonwealth's Attorney may not have been the appropriate vehicle for so ruling, the Virginia statute is clearly void in at least one respect. To the extent that a lawfully married couple might be prosecuted for engaging in the proscribed conduct in the privacy of their home, the law presumably runs afoul of Griswold. ${ }^{96}$ Attempts to use the Griswold-Eisenstadt dichotomy to overturn convictions of unmarried adults for heterosexual sodomy, however, have met with only limited success, ${ }^{97}$ perhaps because the factual setting of cases raising this issue often involved conduct that was not purely private or, more commonly, was part of an alleged sexual assault.

moral force of the criminal law of the land. Many citizens, it must be admitted, regard the prohibitions expressly imposed by the law as the utmost limits set to their activities and are prepared to take full advantage of any omission or relaxation. It would be surprising if there are not considerable numbers with this philosophy among those with whom we are concerned in this inquiry, and the removal of the present prohibition from the criminal code will be regarded as condoning or licensing licentiousness, and will open up for such people a new field of permitted conduct with unwholesome and distasteful implications.

Report of the Departanental Commttree on Homosexual Offenses and ProstiTUTION 61 (1957) (dissenting opinion of James Adair), reprinted in L. BlonsCooper \& G. Drewry, Law and Moratity 18 (1976).

96 A number of cases suggest this result. In Cotner v. Henry, 394 F.2d 873 (7th Cir.), cert. denied, 393 U.S. 847 (1968), a sodomy conviction was reversed in a habeas corpus action because the court did not believe Cotner understood that Griswold might provide a constitutionally required consent defense. Thus, the court ruled that his guilty plea should not have been accepted. In Lovisi v. Slayton, 539 F.2d 349 (4th Cir. 1976), the court affirmed denial of habeas corpus relief sought by a husband and wife convicted of sodomy. The acts in question, however, involved a third person; the Lovisis were each convicted on a count charging sodomy with each other, and Mrs. Lovisi was convicted on another count involving sodomy with the third person. The Lovisis also took pictures of some of the acts in question, and the matter came to the attention of authorities when pictures were taken to school by Mrs. Lovisi's teenage daughters. The court of appeals reasoned that the petitioners had waived a constitutional privacy defense by, in effect, admitting outsiders to their marital intimacies. In State v. Bateman, 113 Ariz. 107, 547 P.2d 6, cert. denied, 429 U.S. 864 (1976), the defendant's conviction of sodomy and lewd and lascivious acts was affirmed. The trial court had instructed the jury that consent was a defense, and this instruction was regarded by the court as satisfying the constitutional objections raised. An intermediate appellate court had earlier reversed Bateman's conviction on the ground that consent was a constitutionally required defense and the statute could not be interpreted as permitting such a defense. State v. Bateman, 25 Ariz. 1, 540 P.2d 732 (1975), vacated, 113 Ariz. 197, 547 P.2d 6, cert. denied, 429 U.S. 864 (1976). See also State v. Pilcher, 242 N.W.2d 348 (Iowa 1976); Hughes v. State, 14 Md. App. 497, 287 A.2d 299, cert. denied, 409 U.S. 1025 (1972); State v. Lair, 62 N.J. 388, 301 A.2d 748 (1973); State v. Elliott, 88 N.M. 187, 539 P.2d 207 (1975). See generally Annot., 58 A.L.R.3d 636 (1974).

97 See, e.g., State v. Callaway, 25 Ariz. App. 267, 542 P.2d 1147 (1975), aff'd, 113 Ariz. 107, 547 P.2d 6 (1976), cert. denied, 429 U.S. 864 (1976); State v. Pilcher, 242 N.W.2d 348 (Iowa 1976); State v. Elliott, 88 N.M. 187, 539 P.2d 207 (1975); Annot., supra note 96. 
A typical example of the latter group of heterosexual sodomy cases, State $v$. Lair, ${ }^{98}$ involved a conviction for rape and sodomy. The defendant contended that Griswold would make the New Jersey sodomy statute unconstitutional as applied to married couples and consequently Eisenstadt would make the application of the statute to consensual sodomy practiced by unmarried adults a denial of equal protection. Consent, therefore, was a constitutionally required defense to a prosecution under the statute. Although the New Jersey Supreme Court agreed that Griswold would have the effect urged if a married couple were prosecuted for sodomy under the statute, it refused to accept the Eisenstadt argument. Although the court noted that Eisenstadt did not involve the right of marital privacy, citing a Maryland case refusing to so apply Eisenstadt, it did not answer the argument.

Lair hardly seems to be a correct reading of Griswold-Eisenstadt. If Griswold completely prohibits prosecution of consensual sodomy practiced in private by a married couple, and if Eisenstadt is a purely equal protection case premised upon the right recognized in Griswold, it is difficult to see how the state may more legitimately prosecute private, consensual, heterosexual sodomy between unmarried people than the use of contraceptives by the same people. If Eisenstadt had been a due process case that found no valid state interest in prosecuting for the use of contraception regardless of the user, the distinction drawn in Lair would be much easier, at least superficially, to maintain. Eisenstadt, however, did not so hold, and the refusal to apply it in Lair betrays a hidden judgment respecting the morality of consensual sodomy.

A few courts have been willing to give the privacy rights discussed above a very broad reading in order to invalidate sodomy statutes as facially invalid. In State $v$. Elliot, ${ }^{99}$ the New Mexico Supreme Court so held, sua sponte, in an appeal from a conviction for sodomy and burglary. The court found that New Mexico's sodomy statute violated the right of marital privacy recognized in Griswold and then went on to read Eisenstadt as requiring similar treatment for consenting, unmarried adults. They further recognized a right of privacy in the home, citing Stanley and Ravin, also violated by this statute. Although the defendant did not seem to fit into any of these categories himself, the court held that he could assert the rights of parties that would be violated by the statute's overbreadth. 
The conflicting and sometimes illogical decisions generated in the modern domain of substantive due process manifest an underlying uncertainty respecting the appropriate method of constitutional analysis, and, often, an insensitivity to the jurisprudential roots of individual liberty. In the Supreme Court, both majority and individual opinions have tended toward polar views. The dominant approach recently has been to formulate very narrowly defined types of individual liberty, such as the Stanley right to possess obscenity in the home, the Griswold right to privacy in the marital relation, and the decisional privacy enunciated in Roe $v$. Wade, and then to examine the legislative purpose to see if some compelling interest justifies the intrusion upon the new-found liberty. If this crystallizing of discrete personal rights is somewhat analogous to the incorporation doctrine most prominently displayed in criminal procedure cases, ${ }^{100}$ one might also expect to find a highly generalized formulation of privacy theory whereby due process protects those rights that are "implicit in a concept of ordered liberty." 101 The vice of both extremes is largely the same-very little guidance is given to the lower federal and state courts that must either engage in the elusive search for the scope and authority of the penumbral right defined in Griswold, or must continually face the challenge of rebalancing individual and state interests inherent in the "ordered liberty" thesis. The balance of this Article attempts the first step in articulating a principled modern theory of substantive due process by placing the question in the context of a traditional jurisprudence of individual rights.

II.

No serious philosopher or jurist would contend that individual liberty means the right of a person to do anything he wishes. In the words of John Locke, "though this be a state of liberty, yet it is not a state of licence . . . ."102 The need for some degree of restraint creates the basic relationship between the individual and the government. Although the current function of government is more complex than ever before and promises to increase in complexity, the basic role of government remains unchanged. Government exists primarily to provide security for the persons and prop-

100 E.g., Duncan v. Louisiana, 391 U.S. 145 ( 1968 ); Malloy v. Hogan, 378 U.S. 1 (1964).

101 Palko v. Connecticut, 302 U.S. 319, 325 (1937).

102 J. Locke, Of Civn Governament 119 (1924) (Ist ed. London 1690). 
erty of its citizens, and it does so by placing limits on the lawful actions of its citizens.

In describing the power of government formed by the social contract of the people, Locke observed:

A man, as has been proved, cannot subject himself to the arbitrary power of another; and having, in the state of Nature, no arbitrary power over the life, liberty, or possession of another, but only so much as the law of Nature gave him for the preservation of himself and the rest of mankind, this is all he doth, or can give up to the commonwealth, and by it to the legislative power, so that the legislative can have no more than this. Their power in the utmost bounds of it is limited to the public good of society. It is a power that hath no other end but preservation .... ${ }^{103}$

Historically, the two approaches taken toward this basic proposition are similar to the divergent modern views of constitutional protection of privacy. ${ }^{104}$ Locke himself and natural law theorists might inquire as to the essential and inalienable elements of liberty. The school of sociological jurisprudence, exemplified by the writings of Dean Roscoe Pound, would balance the government's interest in providing security against the demand of individual liberty. ${ }^{105}$ The approach of Locke and of natural law proponents is based upon a belief in absolute values; ${ }^{106}$ there is a certain composition to liberty to which time and custom are irrelevant. Nature or some other source of authority higher than positive law has established an order that man must discover and toward which he must aspire. However attractive the notion of absolute values may seem, changing social and political conditions have rendered the search an exercise in futility. The quest has not been pointless, however. Because of the influence of natural law theory, many revered doctrines and principles have been integrated into positive law. The Bill of Rights with its enumeration of inalienable guarantees is an example of such influence.

The Bill of Rights guarantees that comprise our basic understanding of individual liberty may find their origin in natural law absolutism, but the interpretation of these guarantees may nevertheless require the reconciliation of competing interests. Pound

$103 \mathrm{Id} .185$.

104 See text accompanying notes 100-01 supra.

105 R. POUND, Contemporary JuRustic ThEORy 57-83 (1940).

106 See W. Friedmann, Legat Theory 95-156 (5th ed. 1967). 
believes that "it is convenient to classify the interests of which the legal order must take account as individual or public or social." 107 Although he points out that all interests are those of individual human beings, most interests are shared by others and may be regarded as joint or social interests. Nevertheless, social interests may not necessarily also be classified as individual interests. Indeed, Julius Stone concluded that the category "public" interest is superfluous:

The main "public interests" in Professor Pound's view, are, first, the interests of the state as a juristic person, comprising its interests of "personality" and "substance", and second, the interests of the state as a guardian of social interests. But these latter consist merely of certain social interests, which can be considered as such, looked at from the viewpoint of official superintendence and initiative in their legal enforcement. The official superintendence and initiative is no reason for creating a class of "public interests" any more than the fact that some social interests are secured by the criminal law is a reason for doing so. ${ }^{108}$

Stone makes a necessary and important distinction between those interests of the state as a juristic entity, which assume a separate and unique character, and those interests that the state protects as a vehicle for enforcing the will of the majority. The latter category clearly represents a common interest of society in preventing harm to others. But the former class of interests is more questionable in that the state has no legitimate interest of its own that outweighs individual liberty-the state has no identity beyond the collective interests and identities of its citizens. To enforce interests premised on the "tone" or "decency" of society is to assert just such a "personality" interest of the state, which is not properly within its sphere of concern.

In the instance of individual actions viewed by a majority of society as immoral and punished as such through the criminal law, a balance must be struck between the right of an individual to follow his conscience (or perhaps to disregard his conscience), and the rights of others, individually and collectively, to be secure in their persons and property. ${ }^{109}$ Obviously, some individual actions,

107 R. Pound, supra note 105 , at 61 .

108 J. Stone, The Province and Function of Law 492 (1950).

109 The right to be secure in one's person and property is not easily defined. In describing the limitations nature places upon man's actions, Locke said that "no 
such as murder, rape, larceny, and fraud, however desirable they may seem to the actor, are clearly violative of the rights of others and the collective interests of society under any philosophical construct. Societal condemnation of other conduct such as marijuana use, consensual sodomy, and abortion is not so clearly necessary to the legitimate functions of government.

A balancing process has widespread acceptance in the American legal system in the formulation of constitutional doctrine. ${ }^{110}$ American government, national and state, is limited by a constitution that specifically protects certain individual rights against majority authority. ${ }^{111}$ The natural law personal liberties reserved to the people in the Bill of Rights and the fourteenth amendment ${ }^{112}$ are not specific and self-executing, however. Although strict constructionists like the late Justice Black may argue for a literal interpretation of various amendments, ${ }^{113}$ one suspects that balancing nevertheless occurs in defining the scope of the "absolute" right in question.

What are the demands of societal security that legitimate the coercion of individual members of society? This is the question to which John Stuart Mill delivered what he believed to be an absolute and timeless answer:

The object of this Essay is to assert one very simple principle, as entitled to govern absolutely the dealings of society with the individual in the way of compulsion and control, whether the means used be physical force in the form of legal penalties, or the moral coercion of public opinion.

one ought to harm another in his life, health, liberty or possessions. ... ." J. LockE, supra note 102. The difficult questions conceming the morality and legitimacy of governmental regulation of conduct through criminal sanctions do not arise in those instances in which the punished conduct inflicted some observable physical harm upon another's person or property. They arise in those situations where the purported "criminal" conduct caused, at worst, some intangible harm to other people or, more typically, to such ephemeral values as the "right of the Nation and of the States to maintain a decent society ...." Jacobellis v. Ohio, 378 U.S. 184, 199 (1964) (Warren, C.J., dissenting). Any effort to define the reach of legitimate governmental interests in protecting the persons and property of its citizens ultimately poses the same difficult questions as those found in defining the precise nature of individual freedom from the coercive restraints of government. Any attempt to define individual liberty premised on an arbitrarily restrictive definition of governmental interests in protecting the security of its citizens would be circular reasoning. Accordingly, no effort will be made at any such precise definition.

110 See, e.g., Roe v. Wade, 410 U.S. 113, 154 (1973).

111 See W. FrIEdManN, supra note 106, at 419-21.

112 Id. 136-51.

113 See Roth v. United States, 354 U.S. 476, 508 (1957) (Douglas, J., dissenting); Dennis v. United States, 341 U.S. 494, 579 (1951) (Black, J., dissenting); A. Bickel, The least Dangerous Branch 93-97 (1962). 
That principle is, that the sole end for which mankind are warranted, individually or collectively, in interfering with the liberty of action of any of their number, is selfprotection. That the only purpose for which power can be rightfully exercised over any member of a civilized community, against his will, is to prevent harm to others. His own good, either physical or moral, is not a sufficient warrant. He cannot rightfully be compelled to do or forbear because it will be better for him to do so, because it will make him happier, because, in the opinions of others, to do so would be wise, or even right. These are good reasons for remonstrating with him, or reasoning with him, or persuading him, or entreating him, but not for compelling him, or visiting him with any evil in case he do otherwise. To justify that, the conduct from which it is desired to deter him, must be calculated to produce evil to some one else. The only part of the conduct of any one, for which he is amenable to society, is that which concerns others. In the part which merely concerns himself, his independence is, of right, absolute. Over himself, over his own body and mind, the individual is sovereign. ${ }^{114}$

Central to Mill's formulation is the concept of "harm to others." His work reveals that ultimately he was no more capable than others who sought to define this concept.

Two arguments may be raised against Mill's theory that do not rely on a theoretical underpinning of the phrase "harm to others." The first and clearest line of dispute was initially espoused by Mill's most critical contemporary, Judge James Fitzjames Stephen. In Liberty, Equality, Fraternity, ${ }^{115}$ written as an answer to Mill, Judge Stephen adopted what H. L. A. Hart has characterized as an "extreme thesis." 116 Under this approach, "the enforcement of morality is regarded as a thing of value, even if immoral acts harm no one directly, or indirectly by weakening the moral cement of society." 117 Even the majority opinion in Paris Adult Theatre I $v$. Slaton ${ }^{118}$ would not go so far as Stephen does in asserting that there are no

$114 \mathrm{~J}$. MIIL, ON LneERTy (1859), reprinted in J. BenteadM, The Uturtarians 483-84 (1961). This passage was quoted by Justice Kavanaugh of the Michigan Supreme Court in the decision reversing John Sinclair's conviction for marijuana possession, discussed more fully at note 9 supra. People v. Sinclair, 387 Mich. 91, 133, 194 N.W.2d 878, 896 (1972).

115 J. Stephen, Luberty, Equality, Fraternity (R. J. White ed. 1967).

116 H. L. A. HART, LAw, Liberty AND Moral.try 48-60 (1963).

117 Id. 49.

118413 U.S. 49 (1973). 
substantive limits that may be legitimately imposed on the will of the majority. Stephen's attitude is suitably characterized as "extreme"; such a theory is repugnant to even the most grudging conception of liberty. ${ }^{119}$ The restriction of individual liberty for no better reason than the will of the majority, no matter how strong their conviction or repugnance at a particular course of conduct, is, as Mill suggested, a "tyranny of the majority." 120 Such a philosophy is certainly at odds with the spirit and intention of our Federal Constitution, if not the specific language in many situations.

Another line of dispute that might be taken with Mill's general proposition would be to question his assertion that the individual, freely in control of his own destiny, should have the right to engage in conduct harmful only to himself. Proponents of the opposite view believe that government intervention solely to protect individuals from self-inflicted harm is legitimate. ${ }^{121}$ They further dispute Mill in asserting that it is difficult to envision a pure example of conduct involving no risk of "harm to others."

110 Judge Stephen's views were extreme but not absolute. Consider, for example, the following excerpt:

The real difference between Mr. Mill's doctrine and mine is this. We agree that the minority are wise and the majority foolish, but Mr. Mill denies that the wise minority are ever justified in coercing the foolish majority for their own good, whereas I affirm that under circumstances they may be justified in doing so. Mr. Morley says that Mr. Mill's principle would protect the minority from being coerced by the majority, whereas my principle would expose them to such coercion. My answer is that in my opinion the wise minority are the rightful masters of the foolish majority; and that it is mean and cowardly in them to deny the right to coerce altogether for fear of its being misapplied as against themselves. The horse is stronger than the rider in one sense, but a man who maintained that horses and men ought to be entirely independent of each other for fear of the horses riding the men would be a very poor creature. In many respects one wise man is stronger than a million fools. The one man in a million who possesses extraordinary intellect, force of character, and force of sympathy is more likely to coerce the rest than they are to coerce him, and I affirm his right in certain cases to do so. Mr. Mill is so timid about the coercion of the one man (who has no business to permit himself to be coerced) by the many, that he lays down a principle which confines the one man to a way of acting on his fellow creatures which is notoriously inoperative with the vast majority of them.

J. STEPHEN, supra note 115 , at 32 .

$120 \mathrm{~J}$. MrI, supra note 114 , at 478 .

121 The force of any such argument ultimately depends upon one's willingness to assume that the individuals in a society, or at least some of them, are incapable of making rational or informed decisions about their own wellbeing. Such an assumption has clearly been made in American jurisdictions with respect to individuals who have not attained the age of majority or who suffer from some mental disease or defect. Whatever might be said about the legitimacy or wisdom of statutes placing restrictions on the rights of minors and incompetents, they are an established part of our legal system and are not questioned here. 
Even these proponents of government paternalism who would not restrict government intervention to situations involving harm to others cannot argue absolutely that the government may intervene to prevent all actions that harm only the actor. The motivation of the actor must be considered in evaluating whether society will allow an individual to take risk upon himself. Ironically, society tolerates dangerous actions taken out of both altruism and the desire for financial gain.

Mill proposed a hypothetical in which the only harm would fall upon the actor himself. He posits the example of a person who wishes to walk across a dangerous bridge, ${ }^{122}$ suggesting that unless the person were under age or not fully possessed of his reasoning capacities, we might do no more than warn him of the bridge's danger. If the person wished to proceed in spite of the danger, then he should be free to do so. Under Mill's construct, it must be assumed that, should this person fall from the bridge, his death would cause no harm to any other person. Any harm to others, such as the danger to those standing below or the termination of financial support of those who depend upon this individual, would justify the proscription of such conduct. ${ }^{123}$

If under Mill's test it could be said that no harm would result to others, although this is admittedly highly unlikely, it is difficult to construct a consistent theory in support of government restraint. Society would hardly censure an individual who was crossing the bridge to assist another person in distress. What if he were doing so for financial gain? We frequently permit individuals to undertake grievous risks for uncertain gain under situations presenting a greater risk of harm to others than in Mill's hypothetical. What of mountain climbers, or motorcycle daredevils? Would a theory tolerating certain types of "harm to oneself" allow an individual to end his life because of extreme pain from some terminal illness?

The point is simply that, aside from the government's right to interfere with action that would harm others, none would argue that action that harms only the actor is always suppressible. Even those who uphold such paternalistic interference by the state must draw a line within the latter class of activities. Although he accepts most of Mill's general theory, Hart differs sharply on this question. ${ }^{124}$

$122 \mathrm{~J}$. Mrx, supra note 114 , at 576.

123 The potential "harm to others" discussed in this section of the text cuts much broader than the attempted definition of this phrase in later sections of the text. See text accompanying notes 143-44 infra.

$124 \mathrm{H}$. L. A. HART, supra note 116, at 30-34. 
Referring to Mill's criticisms of laws restricting or prohibiting the sale of drugs, Hart says that Mill carried his protests to fantastic lengths, suggesting a parallel between these views and the laissez faire economic doctrine of Mill's day. Generally Hart observes that people do not really make the kind of free choices as to their destiny that Mill's doctrine would suppose, undercutting Mill's assumption that some individual actions indeed pose no harm to others.

Mill's theories as to self-destructive action are hardly as incredible as Hart declares, however. Treatment of such actions in American criminal law is far from consistent, and, on the whole, few regulations are aimed solely at protecting the offender. Prosecution for attempted suicide is practically unheard of. One need only read Paris Adult Theatre $I$ to know that laws directed at the sale and use of pornography are motivated more by a concern for the "decency" or "tone" of society or a desire to punish the purveyors of these commodities, rather than a sincere wish to protect the user from himself. The same may plausibly be said for proscriptions of the sale or use of drugs or alcohol. Even motorcycle helmet laws have been upheld against due process attack by hypothesized rationales stressing protection of individuals other than the cyclist. ${ }^{125}$ Moreover, many dangerous or self-destructive acts motivated by a desire for thrills or financial gain are permitted, simply because such acts are not regarded as immoral. Most, if not all, self-destructive acts punished by the criminal law in this country are proscribed primarily because of some real or imagined "harm to others," although no consistent standard for such a finding appears to exist.

Mill's own interpretation of "harm to others" is scarcely more elucidating. In describing the standards of conduct that individuals should observe toward the rest of society, Mill set out two general duties: first, that conduct may not injure those interests of others which, "either by express legal provision or by tacit understanding, ought to be considered as rights"; ${ }^{126}$ and secondly, each must bear his "share of the labors and sacrifices incurred for defending the society or its members from injury and molestation." 127 These

123 See, e.g., Kingery v. Chapple, 504 P.2d 831 (Alaska 1972); Everhardt v. City of New Orleans, 253 La. 285, 217 So. $2 d 400$ (1968), appeal dismissed, 395 U.S. 212 (1969); State v. Mele, 103 N.J. Super. 353, 247 A.2d 176 (1968). Cf. State v. Lee, 51 Haw. 516, 465 P.2d 573 (1970) (upholding helmet law designed primarily to mitigate harm that motorcyclist may visit upon himself). See generally Comment, Limiting the State's Police Power: Judicial Reaction to John Stuart Mill, 37 U. C\#r. L. REv. 605 (1970).

$126 \mathrm{~J}$. MILL, supra note 114 , at 552.

127 Id. (parenthetical omitted). 
"duties" do little to clarify the concept of "harm to others," and the second is particularly unenlightening. Obviously, any type of selfdestructive action could be considered a violation of this latter duty. The alcoholic or drug addict has certainly decreased his usefulness to society. As Lord Devlin observed, "A nation of debauchees would not in 1940 have responded satisfactorily to Winston Churchill's call to blood and toil and sweat and tears." 128

Despite the ambiguity of Mill's language, he would presumably require a direct and perceptible harm to others. He states:

Whenever, in short, there is a definite damage, or a definite risk of damage, either to an individual or to the public, the case is taken out of the province of liberty, and placed in that of morality or law.

But with regard to the merely contingent, or, as it may be called, constructive injury which a person causes to society, by conduct which neither violates any specific duty to the public, nor occasions perceptible hurt to any assignable individual except himself; the inconvenience is one which society can afford to bear, for the sake of the greater good of human freedom. ${ }^{129}$

Of course, this articulation is still unclear. As Professor Packer has observed:

To begin with, it has to be conceded that Mill's formula solves very little. Later in his essay Mill extends his concept of "harm to others" to include "risk of damage" to the interests of others, and it is usually possible to make a more or less plausible argument that any given form of conduct involves that risk in some way. The question is not one of whether or not there will be harm done; it is one of the remoteness and probability of the harm. Some things are more harmful than others. Homicide is more harmful than muttering voodoo incantations; rape is more harmful than reading dirty books. And in a world of limited resources, we need to draw discriminations about the gravity and remoteness of harms. Seen in this light, "harm to others" is a prudential criterion rather than a hard and fast distinction of principle. ${ }^{130}$

Although Mill's principles are far from precise, they furnish a suffciently positive statement of policy to demarcate Mill and his modern

128 Devlin, Mill on Liberty in Morals, 32 U. CHL. L. REv. 215, 224 (1965)

$129 \mathrm{~J}$. Mir., supra note 120 , at 560 .

130 H. Packer, The Limts of the Criminal Sanction 266 (1968). 
critics who would define "harm to others" in broader fashion to encompass whatever is considered morally reprehensible by the majority of society.

Debate over this issue has been sparked anew in England in recent years, primarily between Lord Patrick Devlin and Professor H. L. A. Hart. The impetus for this renewal of interest was largely furnished by the Report of the Departmental Committee on Homosexual Offenses and Prostitution, commonly known as the Wolfenden Report. That study recommended that private homosexual conduct between consenting adults no longer be made criminal, and that prostitution offenses be limited. The Committee observed that, with regard to sexual morality, the function of the criminal law was

to preserve public order and decency, to protect the citizen from what is offensive or injurious, and to provide sufficient safeguards against the exploitation and corruption of others, particularly those who are specially vulnerable because they are young, weak in body or mind, inexperienced, or in a state of special physical, official or economic dependence. ${ }^{131}$

Using language strongly reminiscent of Mill, the Committee stated, "Unless a deliberate attempt is to be made by society, acting through the agency of the law, to equate the sphere of crime with that of sin, there must remain a realm of private morality and immorality which is, in brief and crude terms, not the law's business." ${ }^{132}$ This statement of philosophy, perhaps to a greater extent than the Committee's actual recommendations, elicited Lord Devlin's dissent.

Lord Devlin's basic argument is that society, or a majority of its members, has a right to establish certain moral standards. ${ }^{133}$ These standards are based upon moral principles so deeply held by a majority of citizens as to form an integral and indispensable part of the societal framework. Violation of these moral precepts threatens the very foundations of society. Apparently Devlin would identify these elementary moral principles by gauging the reaction to their violation. If society reacts with "intolerance, indignation and disgust," then the moral principles are elementary. ${ }^{134}$

131 Report of the Committee on Homosexuad Offenses and Prosttutution, CMend. No. 247, at 9-10 (1957).

132 Id. 24.

133 See P. Devlin, The Enforcement of Morals (1965); Devlin, supra note 128. For an analysis of Lord Devlin's position, see Dworkin, Lord Devlin and the Enforcement of Morals, 75 Yaxe L.J. 986 (1966).

134 P. Devin, The Enforcement of Morals 17 (1965). 
Devlin's rationale is clearly appropriate for such obviously antisocial acts as murder or robbery. In these instances, the joint interests of all individuals are well defined and uniformly endorse the punishment of such conduct. Societal moral standards need not be the basis for justifying the punishment of murder; the threat to individual liberty posed by murder is self-evident. When other crimes such as consensual sex offenses and peddling pornography are considered, however, reliance upon "elementary moral principles" becomes necessary to justify Lord Devlin's position. This approach prompts Professor Hart to say that Lord Devlin regards morality as a "seamless web." ${ }^{135}$ For Devlin, permitting any form of immorality to go unpunished, even though it is merely homosexual conduct or drunkenness, threatens all of society's moral fiber.

Professor Ronald Dworkin perceives another facet to Lord Devlin's argument. ${ }^{136} \mathrm{He}$ sees in Devlin's position a recognition that the legislature is delegated authority to make moral decisions in order to preserve and maintain certain environmental and institutional values. These values are then entitled to legal protection from those whose immoral activities threaten to undermine them. Under this analysis, immorality may be roughly equated with treason. ${ }^{137}$

Dworkin adds a gloss to Devlin's theory by identifying the "master plan" of the legislature as the source of moral precepts rather than Devlin's vaguely articulated notion of social custom and moral vision. Perhaps Dworkin's refinement is in recognizing the necessary element of arbitrariness in allowing the legislature to carry out society's ethical consensus. His refinement may not be entirely persuasive, however. Legislative action to proscribe "immoral" acts is probably compelled simply by widely and strongly felt public distaste for certain conduct, or by a legislative prejudice or vague opinion that certain conduct is harmful and must therefore be suppressed.

Lord Devlin's work may have been intended as prescriptive, but its basic impact is more descriptive of current practice. It reflects the realities of our legal system better than the analysis of any other commentator or philosopher. Lord Devlin would presumably have little difficulty accepting the analysis of the majority in Paris Adult Theatre I v. Slaton. ${ }^{138}$ Even though the Supreme Court has been

135 H. L. A. HART, supra note 116, at 51.

136 See Dworkin, supra note 133.

137 See H. L. A. HART, supra note 116, at 49 .

138413 U.S. 49 (1973). 
less than consistent in its recognition of various individual liberties, by refusing to require the state to demonstrate that its criminal proscriptions are directed at actions causing tangible harm to others, the Court falls much closer to Lord Devlin than to Mill.

Lord Devlin pays at least lip service to Mill's general criterion of "harm to others," but his expansive interpretation of that concept is wholly alien to Mill's own application and interpretation. Devlin's leading contemporary critic, Professor Hart, endorses many of Mill's views, but, as the discussion of paternalism indicates, he does not accept Mill's doctrine in its entirety. ${ }^{139}$ Hart disagrees with Devlin's societal view of "harm to others" in large part because he does not accept Devlin's "factual" assertion that violation of certain moral codes will undermine the structure of society. ${ }^{140}$ Hart's concept of "harm to others," however, also differs from Mill's. He would justify some criminal laws on the grounds that a defendant himself constitutes a "nuisance" to society. ${ }^{141}$ This ambiguous term is never precisely defined by Hart, and it would seem that by such characterizations of various types of proscribed immoral conduct, one could ultimately arrive at a position that does not differ greatly from Devlin's. ${ }^{142}$

In order for the concept of individual liberty to have an acceptable substantive content, some definition of harm to society close to Mill's original conception should be chosen. The formulation of such a constitutional principle should be neutral and flexible with respect to specific types of governmental action. ${ }^{143}$ It should

139 See H. L. A. Hart, supra note 116.

140 Id. 50.

141 Id. 41.

142 Hart himself, of course, did not arrive at Devlin's position. He distinguishes private actions from their public display, and would outlaw private consensual acts only for their necessarily public consequences. Bigamy, a public declaration of infidelity, is Hart's only example of a "nuisance." Id.

143 See A. Brchet, The Supreme Court and the Idea of Progress (1970); Wechsler, Toward Neutral Principles of Constitutional Law, 73 HARv. L. REv. I (1959). A recent Article, Perry, Substantive Due Process Revisited: Reflections on (and Beyond) Recent Cases, 71 Nw. U.L. Rev. 417 (1976), criticizes the Alaska Supreme Court decision in Ravin for apparently endorsing the libertarian political views of John Stuart Mill and elevating them to constitutional status. "Whether or not the Alaska Constitution enacts Mill's On Liberty, surely the United States Constitution no more enacts On Liberty than it enacts Mr. Herbert Spencer's Social Statics." Id. 434 (footnotes omitted). The final footnote to this sentence cites Mr. Justice Holmes' famous dissent in Lochner and poses the apparently unanswerable question: "By what imaginable warrant could the Justices of the United States Supreme Court defensibly impose Mill's political philosophy on the American people?" Id. n.110 (emphasis in original).

Although the present Article presumes to do no more than suggest that Mill's political philosophy provides a reasonable frame of reference for evaluating the constitutional validity of criminal laws, I feel compelled to offer at least a partial 
not forever sanctify certain types of conduct, by placing the prosecution of private homosexual acts, the procreation of children, or motorcycle riding without a helmet, for example, beyond the power of the government to regulate or proscribe. Such rigid formulations are a denial of the balancing process that must always be used in accommodating the individual's interest in personal liberty with the legitimate interests of society in protecting the persons and property of all citizens. A suggested test to be applied when considering the validity of a criminal statute faced with a due process challenge is: Does the conduct proscribed under this statute entail a substantial risk of direct physical, emotional, or financial harm to individuals not consenting to the conduct in question?

This rule is an adaptation of Mill and a reflection of the balance that must be struck between individual and societal interests. It obviously does not represent a precise formula, however. What does "substantial" mean? How much physical, emotional or financial harm should be countenanced, if any? It is impossible to quantify conduct so as to give a precise answer to these questions. Rulings as to the validity of specific statutes must emanate from an application of the formula in the light of both its policy and philosophical underpinnings. The principle would not exist in a vacuum; rather, it would acquire more precise meaning after its application to specific cases, which in turn furnish a reservoir of precedential sources. The formula should ultimately be viewed, as Justice Harlan urged, with regard to the phrase "due process of law":

response to Professor Perry's general comment. In my opinion, a philosophy asserting that the forces of a free market must be permitted to control the economic life of the nation, regardless of the consequences in terms of "harm" to the citizenry, ultimately conflicts with a philosophy that requires government to refrain from coercing its citizens except where there is a demonstrable harm or threat of harm to other citizens if the government fails to act. On Liberty is no more analogous to the economic Darwinism epitomized by Social Statics than democracy is analogous to anarchy. Moreover, I believe that Mill's philosophy really goes to the processes of government; it tries to identify the kinds of factors government should weigh before deciding to take action in some area. Laissez faire economic philosophy, on the other hand, involves a particular substantive decision that its adherents would require government to make, that is, let the commercial sector take care of itself without governmental interference and the country will be better off.

Professor Perry would apply a doctrine of substantive due process that would require laws aimed at "promoting the public morals and serving no other purpose," id. 443 (footnote omitted), to be compared with "conventional morality" for the purpose of deciding whether the law truly reflects the "public morals" id. 441-51. Freely admitting the difficulties in defining the concept of "harm to others," I nevertheless find it conceptually superior to an approach based upon a search for "conventional morality." Professor Perry's approach seems to mirror the philosophical position of Lord Devlin with a liberal gloss. See text accompanying notes 130-39 supra. 
Due process has not been reduced to any formula; its content cannot be determined by reference to any code. The best that can be said is that through the course of this Court's decisions it has represented the balance which our Nation, built upon postulates of respect for the liberty of the individual, has struck between that liberty and the demands of organized society. If the supplying of content to this Constitutional concept has of necessity been a rational process, it certainly has not been one where judges have felt free to roam where unguided speculation might take them. The balance of which I speak is the balance struck by this country, having regard to what history teaches are the traditions from which it developed as well as the traditions from which it broke. That tradition is a living thing. A decision of this Court which radically departs from it could not long survive, while a decision which builds on what has survived is likely to be sound. No formula could serve as a substitute, in this area, for judgment and restraint. ${ }^{144}$

Although Harlan's overall philosophy would not necessarily square with that embodied in the formula recommended here, his approach to constitutional interpretation is consistent.

The above rule amounts to a "neutral principle" in the only meaningful sense. It is not neutral in the sense that it expresses no policy or prejudice against certain types of governmental action; it is neutral, however, in that it does not purport to be a rigid, hardand-fast delineation of the acceptable and unacceptable. It does not purport to decide specific cases beyond the purview of the immediate controversy.

The proposed rule must be elevated to the level of a constitutional standard. "Due process of law," as that phrase is used in the fifth and fourteenth amendments, is widely recognized to entail a substantive meaning beyond the procedural interpretation that the words themselves suggest. The incorporation of the first amendment into the fourteenth is a rather obvious example of substantive due process, as is the right of marital privacy adopted in Griswold and the right of a woman to make decisions about securing an abortion. ${ }^{145}$ Various Supreme Court cases recognize a substantive content to the concept of individual liberty, sanctioned by the re- 
quirement of due process that transcends the literal meaning of the Bill of Rights.

To the extent, however, that the Court ventures beyond the literal language of specific constitutional provisions in finding and enforcing substantive individual rights, it becomes vulnerable to charges that it is operating as a "super-legislature." Criticizing the decision in Roe v. Wade, Professor Ely observed: "What is frightening about $R o e$ is that this super-protected right [that of a woman to choose to have an abortion] is not inferable from the language of the Constitution, the framers' thinking respecting the specific problem in issue, any general value derivable from the provisions they included, or the nation's governmental structure." 146 Others have attempted to answer this sort of criticism by analyzing Roe as a case that protected values inferable from the establishment clause of the first amendment ${ }^{147}$ or as reflective of the implicit limitation on exercise of the police power to those matters involving the "public welfare." 148 Either or both of these approaches might be utilized to ground the substantive rights discussed here in specific constitutional language.

In addition, the Court has frequently felt competent to interpret the general language of the due process clause in such a way as to protect particular aspects of personal liberty that find no specific expression in other constitutional language. As Justice Goldberg observed:

[A] judicial construction that this fundamental right [privacy in marriage] is not protected by the Constitution because it is not mentioned in explicit terms by one of the first eight amendments or elsewhere in the Constitution would violate the Ninth Amendment, which specifically states that " $[t]$ he enumeration in the Constitution, of certain rights, shall not be construed to deny or disparage others retained by the people." 140

This Article adheres to Justice Goldberg's formulation, but beyond this there is little similarity between the present proposal and the constitutional analysis employed by the modern Court. To

146 Ely, The Wages of Crying Wolf: A Comment on Roe v. Wade, 82 YALE L.J. $920,935-36$ (1973).

147 Tribe, Foreword: Toward a Model of Roles in the Due Process of Life and Law, 87 Harv. L. Rev. 1, 18-25 (1973).

148 Perry, Abortion, The Public Morals, and the Police Power: The Ethical Function of Substantive Due Process, 23 U.C.L.A. L. REv. 689 (1976). See also Perry, supra note 143, at 452.

149 Griswold v. Connecticut, 381 U.S. 479, 491-92 (1965). 
the extent generalizations are possible, the Court, when confronted with a claim that a particular governmental action violates due process, first attempts to label the specific right as narrowly as possible. Once isolated, the right is then classified as fundamental or not. If a fundamental right is involved, governmental action infringing it must be supported by some compelling governmental interest. ${ }^{150}$ A nonfundamental liberty may be infringed by any governmental action that bears a rational relationship to some objective within the government's power. ${ }^{151}$ The entire case will thus revolve around the process of labeling and classifying the individual right involved. If a statute must be predicated upon a compelling interest, it is virtually certain to be invalidated, but if only a rational relationship between means and ends need be shown, the individual bringing the challenge will rarely be able to overcome the presumption of constitutionality. ${ }^{152}$

In the context of the specific types of criminal statutes discussed earlier, proscription of marijuana sale and possession, sodomy, and obscenity, the present Court would probably not find any fundamental rights infringed. Presumably no fundamental right exists to use marijuana or view dirty movies. This type of approach, however, bypasses the really crucial issue. Courts are not being asked to decide whether the Constitution implicitly says anything about smoking marijuana; they are being asked if there is any good reason for putting someone in jail for smoking marijuana. No principled evaluation of these cases can avoid reference to the broader social purpose of a criminal prosecution. ${ }^{153}$

${ }_{150}$ Roe $v$. Wade is a prime example of this type of constitutional analysis. In San Antonio Independent School District v. Rodriguez, 411 U.S. 1 (1973), an equal protection case, the majority opinion of Justice Powell and a dissenting opinion by Justice Marshall, id. 70, provide good examples of the Court's reasoning process in labeling rights and classifying them as fundamental or not. See Note, On Privacy: Constitutional Protection for Personal Liberty, 48 N.Y.U. L. REv. 670, 701-05 (1973).

151 The cases in which the rational relationship test was used to uphold state and federal legislation are legion. Paris Adult Theatre $I$ v. Slaton is an example of such cases. If one ignores early substantive due process cases such as Lochner v. New York, 198 U.S. 45 (1905), and a few equal protection cases which employed this standard, e.g., Eisenstadt v. Baird, 405 U.S. 438 (1972), and Reed v. Reed, 404 U.S. 71 (1971), it is difficult to find cases in which a rational relationship was found lacking.

152 Only two Supreme Court cases have upheld a statute which infringed a "fundamental right." One of these is Roe v. Wade. Although the statute at issue was declared unconstitutional, the Court found that protecting the fetus after viability was a compelling enough reason to justify infringing the woman's right of privacy. In Korematsu v. United States, 323 U.S. 214 (1944), the war emergency was found compelling enough to abridge the rights of those with Japanese ancestry.

153 Society seeks to punish only those whose actions have been shown to violate some tenet of social conduct that is necessary for the protection of persons and property. To achieve this aim without punishing the innocent-those who did not 
The test suggested earlier, can best be explained in the context of a few illustrative situations. In Paris Adult Theatre I v. Slaton ${ }^{154}$ a movie theater showed pornographic films to adults only. If such a business fully advises its patrons of the nature of its product, so that the patrons are truly "consenting," in such a way that passersby or other members of the public do not have a potentially offensive pornographic display thrust upon them, ${ }^{155}$ it is difficult to perceive where the "substantial risk of direct physical, emotional or financial harm" might arise. Even the Supreme Court grudgingly seemed to admit that "there is no conclusive proof of a connection between antisocial behavior and obscene material." ${ }^{156}$ Even though there might be some evidence supporting a link between pornography and violent crime or sexual victimization of minors, this evidence falls far short of establishing a "substantial risk" of such a connection. ${ }^{157}$ The criminal prosecution of a theater owner or patron under these circumstances would offend due process. Obviously this approach does not elevate such nebulous concepts as the tone or decency of society into the status of legitimate governmental interests, the specific content of which are certain to vary depending on the moral values of a given societal majority.

commit such acts, or those whose acts do not warrant punishment-courts employ the concepts of presumption of innocence and due process of law. A presumption of innocence exists in all criminal cases which must be overcome by evidence which establishes guilt beyond a reasonable doubt. This presumption and burden of proof, of course, goes only to the issue of whether the elements of the crime the defendant is charged with violating have been proven. Thus, the legislature might decide, for example, that individuals who grow their hair longer than a particular length present a health hazard and should be jailed. Although the state must prove beyond a reasonable doubt that a particular defendant's hair length exceeded the maximum permitted, the defendant must prove the statute violates due process of law.

A change in the defendant's plea from "I didn't do it," to "I did it but you are abusing your power by punishing me for it," should not work such an abrupt change in his legitimate expectations as to the government's burdens and consequently in his rights. Nevertheless, I am not ultimately arguing that the presumption of constitutionality should be reversed in criminal cases. The principle suggested in text need not require the state to demonstrate affirmatively the "harm to others" occasioned by criminal conduct in the absence of a prima facie showing by the defendant that no such harm results from the conduct in question. See note 15 supra.

154413 U.S. 49 (1973).

155 It would not seem that the prosecution of individuals for a public display of obscene materials runs afoul of the proposed standard. Even if one were to ignore the possibility that minors could view such a public display, the offensive nature of obscenity to many in our society arguably justifies criminal restrictions on public displays. The proposed constitutional standard and the supporting arguments need not protect the purveyor or possessor of pornography in the absence of informed consent by all parties exposed to the material.

156 Paris Adult Theatre I v. Slaton, 413 U.S. 49, 60-61 (1973).

157 See F. Schauer, The Law of Obscentty 58-64 (1976). 
The evidence concerning the harmfulness of marijuana use summarized earlier ${ }^{158}$ tends to produce a similar conclusion as to existing marijuana laws. Although Ravin v. State ${ }^{159}$ essentially produced such a result, the Alaska Supreme Court viewed the drug's harmlessness as important only insofar as the prosecution involved an individual using marijuana in the "privacy of his home." If the relatively benign nature of marijuana makes private consumption in the home beyond the state's power to prohibit, how then, in the absence of some governmental scheme for the orderly distribution of the drug, may the punishment of those who sell to such "private" consumers be justified? How is this "private" consumer to acquire the drug he cannot be punished for using? Because Ravin, following Griswold, rested on the sanctity of the home, it could only conclude that the criminal sanction did not reach so far. The standard proposed here does not depend on the privacy of the home as a basis for constitutional protection-one has a right to engage in conduct that will not harm others regardless of the location of the act. It is absurd to talk about a right to use a product when it remains illegal to purchase the product and illegal to transport it to the place where it may rightfully be consumed. Under our present state of knowledge, no aspect of the marijuana transaction presents the kind of risk of harm to others required by the constitutional standard under discussion.

Ironically, criminal abortion statutes, already declared unconstitutional to the extent that they prohibit abortions before the stage of viability is reached, present the most difficult question under the proposed test of all the types of statutes previously mentioned. Because a potential life is involved in the abortion decision, the state can argue that prohibition of abortions is justified by a desire to prevent "harm to others." The point at which the state's interest in prohibiting abortions becomes compelling under current doctrine, however, the stage at which the fetus becomes viable, ${ }^{160}$ seems to be the only legitimate point at which the state

158 See note 4 supra.

159537 P.2d 494 (Alaska 1975).

160 Although in Roe v. Wade and Doe v. Bolton the point at which the state's interest in protecting fetal life became "compelling" was said to be viability, the opinion suggested that this point was generally reached at the end of the second trimester of pregnancy. In Planned Parenthood v. Danforth, 428 U.S. 52 (1976), the Court upheld a statutory definition of viability as "that stage of fetal development when the life of the unborn child may be continued indefinitely outside the womb by natural or artificial life-supportive systems." Id. 63. Quaere whether advances in medical science that might ultimately make viability occur at conception will eliminate the rights recognized in Roe $v$. Wade or prompt a redrawing of the lines between the women's right to abort and the fetus' right to live. 
can identify a "harm to others" under the proposed standard. As Professor Tribe wrote in defense of the result in Roe $v$. Wade:

Viability thus marks a point after which a secular state could properly conclude that permitting abortion would be tantamount to permitting murder, not because of some illusion that this biologically arbitrary point signals "any morally significant change in the developing human," and certainly not because of any (necessarily religious) notion that the fetus is intrinsically a human being from that technology-dependent point forward, but rather on the secular and quite practical ground that a state wishing to prevent the killing of infants simply has no way to distinguish the deliberate destruction of the latter from what is involved in postviability abortions. ${ }^{161}$

Considerable additional time might be spent detailing the application of the proposed test to a wide variety of existing and potential uses of the criminal sanction, but that would place undue emphasis upon the particular form of words chosen in the test, detracting from the central point set forth in this Article. The power of government to levy criminal sanctions should not be used to impose majoritarian moral values on the rest of society unless those values coincide with the legitimate function of government. At least in this context, the legitimate function should be limited to protecting the persons and property of individuals against the tangibly harmful acts of others. To put an individual in jail for his own good or because his conduct offends some moral precept seems itself immoral and arguably unconstitutional as well. As Herbert L. Packer observed, " $[t]$ he criminal sanction represents a very special kind of law, itself morally hazardous." 162 When an individual is jailed merely because the majority does not like the way he acts, the potential moral hazard posed by the criminal sanction is no longer inchoate.

161 Tribe, supra note 147, at 27-28 (footnotes omitted).

162 H. PAGKER, supra note 130, at 261. 